\title{
ANALISIS PENGARUH VOLUME PRODUK WALET TERHADAP PENYERAPAN TENAGA KERJA DAN PENINGKATAN PENDAPATAN KARYAWAN \\ PT. PERDANA JAYA
}

\author{
*(Titin \\ Fakultas Ekonomi \\ Universitas Islam Lamongan
}

\begin{abstract}
ABSTRAK
Permasalahan ketenagakerjaan masih menjadi masalah utama di Indonesia. Hal ini terlihat dari masih dan terus meningkatnya angka pengangguran, permasalahan upah dan hak tenaga kerja.Serta berbagi masalah ketenagan kerjaan lainya.usaha yang berskala besar ini merupakan salah satu solusi bagi sebagian besar masyarakat lokal untuk mendapat perkerjaan. Usaha walet merupakan usaha produktif di sekitar non pertanian baik untuk mata pencaharian utama maupun sampingan.sebagai salah satu usaha ekonomi.maka usaha walet di kategorikan ke dalam usaha besar atau usaha yang berskala besar.
\end{abstract}

Kata Kunci: Volume produk walet, tenaga kerja dan pendapatan karyawan.

\section{PENDAHULUAN}

Permasalahan ketenagakerjaan masih menjadi masalah utama di Indonesia. Hal ini terlihat dari masih dan terus meningkatnya angka pengangguran, permasalahan upah dan hak tenaga kerja. Serta berbagi masalah ketenagan kerjaan lainya.usaha yang berskala besar ini merupakan salah satu solusi bagi sebagian besar masyarakat lokal untuk mendapat perkerjaan. Hal tersebut di sebabkan karena pada umumnya usaha besar lebih mempriolitaskan untuk mengambil pekerjan dari lingkungan sekitarnya dan tidak terlalu di tuntut untuk memiliki pendidikan tinggi.

Hal yang demikian juga terjadi di desa tunggun kec.Mantup kab.Lamongan yang selama ini di kenal sebagai sentra usaha produk walet. Kondisi yang demikian menyebabkan banyak masyarakat desa untuk berkerja di usaha besar produk walet meski bersifat usaha rumah tangga, tapi hal ini membawa imbas positif terhadap kondisi sosial ekonomi masyarakat sekitar.

Usaha walet merupakan usaha produktif di sekitar non pertanian baik untuk mata pencaharian utama maupun sampingan sebagai salah satu usaha ekonomi.maka usaha walet di kategorikan ke dalam usaha besar atau usaha yang berskala besar. Sektor usaha produk walet semakin menjadi tumpuan harapan bagi masyarakat desa tunggun. Keberadaan suatu industri di suatu wilayah tentu akan mempengaruhi kondisi sosial ekonomi dengan penyerapan tenaga kerja dari masyarakat sekitarnya. Penyerapan tenaga kerja merupakan jumlah tertentu dari tenaga kerja yang di gunakan dalam suatu unit usaha tertentu. Secara tidak langsung akan meningkatkan kesejahteraan dengan memberikan upah terhadap pekerjaannya yang berasal dari pendapatan hasil usaha tersebut.

Walaupun demikian, seringkali di jumpai alasan sebenarnya pembuatan kawasan usaha di desa tersebut adalah 
menekan biaya produksi.Hal ini karena upah buruh masyarakat desa yang relatif jauh lebih rendah di banding dengan masyarakat perkotaan.Keadaan demikian di perpara lagi dengan sistem kontrak yang di terapkan oleh sebagian besar usaha yang semakin memperlemah posisi tawar masyarakat desa.

Hal ini bisa di karenakanoleh pola industrialisasi yang di terapkan di Indonesia.Pengembangan usaha besar yang padat modal dengan prinsip efisiensi di terapkan melalui penggunan alat modern atau canggih sehingga membatasi pengunaan tenaga kerja berdasarkan keahlian tertentu, yang pada gilirannya menyebabkan tersingkirnya sejumlah masyarakat dari sektor tradisional.Pada akhirnya tingkat kesejahteraan masyarakat pedesaan di Indonesia tetap berada dalam situasi memprihatinkan.

Desa tunggun kecamatan mantup, kabupaten lamongan yang menjadi studi kasus penelitian ini, telah berdiri usaha produk walet sejak tahun 2006.Semenjak itu kehadiran usaha tersebut tentu membawah beragam perubahan pada kondisi sosial ekonomi masyarakat serta lingkungan. Oleh karenanya, menarik untuk dikaji lebih dalam bagimana kondisi masyarakat sekarang setelah adanya usaha produk walet khususnya di desa tunggun, maka penulis berdasarkan latar belakang tersebut di atas maka penulis tertarik mengambil judul penelitian "ANALISIS PENGARUH VOLUME PRODUK WALET TERHADAP PENYERAPAN TENAGA KERJA DAN PENINGKATAN PENDAPATAN KARYAWAN PADA PT. PERDANA JAYA."

Berdasarkan latar belakang tersebut diatas maka dapat di rumuskan masalah 1. Apakah volume produk walet berpengaruh terhadap penyerapan tenaga kerja desa tunggun kec. Mantup kab. Lamongan. 2. Apakah volume produk walet berpengaruh terhadap peningkatan pendapatan karyawan desa tunggun kec. Mantup kab. Lamongan. 3. Seberapa besar pengaruh volume produk walet dapat meningkatkan penyerapan tenaga kerja karyawan desa tunggun kec. Mantup kab. Lamongan. 4. Seberapa besar pengaruh volume produk walet dapat meningkatkan pendapatan karyawan desa tunggun kec. Mantup kab. Lamongan.

Tujuan penelitian ini yaitu 1 . Untuk mengetahui apakah volume produk walet berpengaruh terhadap penyerapan tenaga kerja di desa Tunggun kec. Mantup kab. Lamongan. 2. Untuk mengetahui apakah volume produk walet berpengaruh terhadap peningkatan pendapatan karyawan di desa tunggun kec. Mantup kab. Lamongan. 3. Untuk mengetahui seberapa besar volume produk walet dapat meningkatkan tenaga kerja karyawan desa tunggun kec. Mantup kab. Lamongan. 4. Untuk mengetahui seberapa besar volume produk walet dapat meningkatkan pendapatan karyawan desa Tunggun kec. Mantup kab. Lamongan.

\section{METODE PENELITIAN}

Jenis penelitian dalam penelitian penulis adalah deskriptif kuantitatif. Sugiyono(2011:8), mendefinisikan bahwa "kuantitatif dapat diartikan sebagai metode penelitian yang berdasarkan filsafat positivisme yang diteliti melalui data sampel atau populasi. Populasi adalah wilayah generalisasi yang terdiri atas: obyek/subyek yang mempunyai kualitas dan karakteristik tertentu yang di tetapkan oleh peneliti untuk dipelajari dan kemudian ditarik kesimpulanya (Sugiyono, 2012:80). Populasi dalam penelitian ini adalah 100 seluruh karyawan pabrik PT. Perdana Jaya Lamongan. Sampel adalah bagian dari jumlah dan karakteristik yang dimiliki oleh populasi.Sugiyono (2012:81). 
Adapun sampel dalam penelitian ini adalah 50 karyawan pabrik PT. Perdana Jaya Lamongan.

Teknik sampling adalah merupakan teknik pengambilan sampel. Untuk menentukan sampel yang akan di gunakan dalam penelitian, terdapat berbagai teknik sampling yang di gunakan secara skematis Yang akan diambil dalam penentuan sampel dalam penelitian ini adalah Metode Random Sampling (pemilihan sampel acak sederhana sederhana), Cara demikian dilakukan bila anggota populasi dianggap homogen (Sugiyono, 2010:120).

Sumber data adalah subyek dari mana data itu di ambil atau dari mana data itu diperoleh baik dari informasi, foto, buku-buku dan masih banyak lagi. Data ini dapat digunakan untuk memperjelas diskripsi dan analisa (Suharsimi Arikunto, 2010;172) membagi mengidentifikasi menjadi tiga $\mathrm{P}$, yaitu:1). Person, yaitu data yang bisa memberikan data berupa jawaban lisan melalui wawancara atau jawaban tertulis melalui angket.2). Place, yaitu sumber data yang menyajikan tampilan berupa keadaan diam dan bergerak.3). Paper, yaitu sumber data yang menyajikan tandatanda berupa huruf angka, gambar, atau simbol-simbol lain.

Teknik Pengumpulan Data: a). Teknik observasi: Observasi dilakukan untuk memperoleh informasi tentang kelakuan manusia seperti yang terjadi dalam kenyataan. Dengan metode observasi ini peneliti dapat memperoleh gambaran yang lebih jelas dalam mengumpulkan data. Observasi merupakan cara pengumpulan data melalui proses pencatatan perilaku subyek (orang), obyek (benda) atau kejadian yang sistematis tanpa adanya pernyataan atau komunikasi dengan individu-individu yang jelas. (Sanusi, 2011;111) Observasi dapat dilakukan dengan dua cara, yang kemudian digunakan untuk menyebutkan observasi, yaitu: 1). Observasi non-sistematis, yang dilakukan oleh pengamat dengan tidak menggunakan instrument pengamatan. 2). Observasi sistematis, yang dilakukan oleh pengamatan dengan menggunakan pedoman sebagai instrument pengamatan. (Suharsimi arikunto, 2010;200). b). Teknik interview: Yaitu sebuah dialog yang dilakukan oleh pewawancara untuk memperoleh informasi dari berwawancara atau interview (Suharsimi Arikunto,2010;198). Ada dua macam pedoman wawancara: 1). Pedoman wawancara tidak terstruktur, yaitu pedoman wawancara yang hanya memuat garis besar yang akan ditanyakan. 2). Pedoman wawancara terstruktur, yaitu pedoman wawancara yang disusun secara terperinci sehingga menyerupai checklist. Pewawancara tinggal membubuhkan tanda $\mathrm{V}$ (check) pada nomor yang sesuai.Contoh: misalnya kita akan menyelidiki pengetahuan dan pendapatan mahasiswa tentang perguruan tinggi dimana mereka kuliah. Pertama-tama mereka kita tanya tentang tahun berapa masuk, sekarang di tingkat berapa, mengambil mata kuliah apa saja, ekstra kurikuler apa yang diikuti dan sebagainya, kemudian diikuti dengan pertanyaan, antara lain sebagai berikut: Pada tahun berapa saudara masuk, jurusan apa saja yang ada? - Apakah saudara lancar menaiki jenjang dari tahun ke tahun? - Apakah program studi yang diberikan cocok dengan keperluan saudara jika sudah lulus?Dan sebagainya. (Suharsimi Arikunto, 2010;270). c). Teknik dokumentasi: Dokumentasi ialah teknik pengumpulan data yang tidak langsung ditujukan kepada obyek penelitian. Dokumen yang diteliti dapat berupa berbagai macam tidak hanya dokumen resmi dapat berupa harian, surat pribadi, laporan, notulen rapat. Catatan khusus dalam pekerjaan social dan dokumen lainya.Teknik ini sangat 
mendukung dalam rangka melengkapi data-data sekunder dan memanfaatkan sumber-sumber dokumen yang ada didinas koperasi. Relevansinya dengan obyek penelitian, bahwa teknik ini dapat diasumsikan mewakili beberapa data yang dianggap mendasar ke penelitian untuk dijadikan acuan untuk mendeskripsikan usaha besar yang ada di Desa Tunggun Kecamatan Mantup Kabupaten Lamongan.

Operasional Variabel: a) Variabel Independen atau bebasAdalah yang terjadi pertama dari segi waktu yang diperkirakan (Sugiyono,2012:39). Variabel independen yang digunakan dalam penelitian ini adalah Volume Produk Walet (X).

b) Variabel Dependen atauterikat merupakan variabel yang terjadi kemudian atau yang menjadi akibat, karenaadanya variabel bebas (Sugiyono, 2012:39). Variabel dependen yang digunakan dalam penelitian ini adalah Penyerapan Tenaga Kerja (Y1) dan Peningkatan Pendapatan Karyawan (Y2).

\section{Metode Analisis Data}

\section{Koefisien Korelasi Parsial}

Koefisien korelasi parsial digunakan untuk melihat besarnya hubungan antara dua variabel bebas dengan variabel terikat.

Rumus:

$$
\mathrm{r}_{1}=\frac{\mathrm{n} \sum \mathrm{xy}_{1}-\sum \mathrm{x} \sum \mathrm{y}_{1}}{\sqrt{\left(\mathrm{n} \sum \mathrm{x}^{2}-\left(\sum \mathrm{x}\right)^{2}\right)\left(\mathrm{n} \sum \mathrm{y}^{2}-\left(\sum \mathrm{y}_{1}\right)^{2}\right)}}
$$

(Suharyadi dan Purwanto S.K,2013;237)

$$
r_{2}=\frac{n \sum x_{2}-\sum x \sum y_{2}}{\sqrt{\left(n \sum x^{2}-\left(\sum x\right)^{2}\right)\left(n \sum y_{-}^{2}\left(\sum y_{2}\right)^{2}\right.}}
$$

Dimana:

$\mathrm{r}=$ koefisien korelasi

$\mathrm{X}=$ volume produk walet
$\mathrm{Y}_{1}=$ penyerapan tenaga kerja

$\mathrm{Y}_{2}=$ peningkatan pendapatan karyawan

$\mathrm{n}$ =banyaknya data

\section{Analisis Regresi Linier Sederhana}

Analisis regresi linier sederhana adalah hubungan secara linier antara satu variabel independen $(\mathrm{X})$ dengan variabel dependen ( $Y$ ).analisis ini untuk mengetahui arah hubungan antara variabel independen dengan variabel dependen apakah positif atau negatif dan untuk memprediksi nilai dari variabel dependen apabila nilai variabel independen mengalami kenaikan atau penurunan. Data yang digunakan biasanya berskala interval atau rasio.

Rumus regresi linier sederhana sebagai berukut :

$\mathrm{Y}^{\prime}=\mathrm{a}+\mathrm{bX}$

Keterangan :

$\mathrm{Y}^{\prime}=$ Variabel dependen / terikat

$\mathrm{X}=$ Variabel Independen / bebas

$\mathrm{a}=$ Konstanta (nilai $\mathrm{Y}^{\prime}$ apabila $\mathrm{X}=0$ )

$\mathrm{b}=$ Koefisien regresi (nilai peningkatan ataupun penurunan).

\section{Uji t}

Digunakan untuk mengetahui tingkat pengaruh variabel bebas terhadap variable terikat. Uji ini dilakukan dengan cara membandingkan nilai $t$ hitung dengan $t$ table. Jika $t_{\text {hitung }}>t_{\text {table }}$ maka $\mathrm{Ha}$ diterima menolak Ho. Artinya secara parsial variable bebas berpengaruh nyata terhadap variabel terikat. Uji t dapat dilakukan dengan rumus sebagai berikut:

$\mathrm{t}_{\text {hitung }}=\frac{\mathrm{b}_{1}}{\mathrm{sb}_{1}}$

(Suharyadi dan purwanto S.K, 2013;238)

Dimana:

$\mathrm{t}_{\text {hitung }}=\mathrm{t}$ hasil perhitungan

$\mathrm{b}_{1}=$ koefisien regresi

$\mathrm{sb}_{1}=$ kesalahan standard koefisien regresi

Setelah dilakukan analisis data maka langkah selanjutnya adalah 
membandingkan nilai signifikansinya dengan taraf signifikansi 0,05. Dari keterangan tersebut dapat ditarik kesimpulan apakah hipotesis nol $\left(\mathrm{H}_{0}\right)$ atauKriteria untuk penerimaan dan penolakan suatu hipotesis adalah:

$>$ Nilai ${ }_{\mathrm{t}}$ hitung $<_{\mathrm{t}}$ tabel, maka hipotesis nol $\left(\mathrm{H}_{\mathrm{o}}\right)$ diterima dan hipotesis alternatif $\left(\mathrm{H}_{\mathrm{a}}\right)$ ditolak.

$>$ Nilai $t$ hitung $>_{t}$ tabel, maka hipotesis nol $\left(\mathrm{H}_{\mathrm{o}}\right)$ ditolak dan hipotesis alternatif $\left(\mathrm{H}_{\mathrm{a}}\right)$ diterima.

\section{HASIL DAN PEMBAHASAN \\ Analisis Data \\ Koefisien Korelasi Parsial}

Untuk membuktikan besarnya hubungan antara dua variabel bebas dengan variabel terikat secara sendirisendiri :

$$
\begin{aligned}
& \mathrm{r}_{1}=\quad \mathrm{n} \sum \mathrm{XY}-\sum \mathrm{Y} \sum \mathrm{X}_{1} \\
& \sqrt{ }\left(\mathrm{n} \sum \mathrm{Y}^{2}-\left(\sum \mathrm{Y}\right)^{2}\right)\left(\mathrm{n} \sum \mathrm{X}^{2}{ }_{1}-\left(\sum \mathrm{X}_{1}\right)^{2}\right) \\
& r_{1}= \\
& \sqrt{ }\left(30(2285)-(259)^{2}\right)\left(30(2047)-(243)^{2}\right) \\
& =\frac{64020-62937}{} \\
& \sqrt{ }(68550-67081)(61410-59049) \\
& =\frac{1083}{\sqrt{3468309}} \\
& =1083 \\
& 1862,34 \\
& =0,581527 \leftrightarrow 0,582
\end{aligned}
$$

Keterangan :

Koefisien korelasi antara penyerapan tenaga kerja dengan pendapatan karyawan diperoleh $\mathrm{r}_{1}=$ 0,582 yang berarti bahwa tenaga kerja pegawai dengan pendapatan pegawai mempunyai pengaruh yang positif dengan kualifikasi agak rendah.

$$
\begin{aligned}
& \mathrm{r}_{2}=\frac{\mathrm{n} \sum \mathrm{YX}_{2}-\sum \mathrm{Y} \sum \mathrm{X}_{2}}{\sqrt{\left(\mathrm{n} \sum \mathrm{Y}^{2}-\left(\sum \mathrm{Y}\right)^{2}\right)\left(\mathrm{n} \sum \mathrm{X}_{2}{ }_{2}-\left(\sum \mathrm{X}_{2}\right)^{2}\right)}} \\
& =\frac{30(2009)-259(228)}{\sqrt{\left.30(2285)-(259)^{2}\right)\left(30(1860)-(228)^{2}\right)}} \\
& =\frac{60270-59052}{\sqrt{(68550-67081)(55800-51984)}} \\
& =\frac{1218}{\sqrt{5605704}} \\
& =\frac{1218}{2367,637} \\
& \mathrm{r}_{2}=0,514437 \leftrightarrow 0,514
\end{aligned}
$$

Keterangan :

Koefisien korelasi antara penyerapan tenaga kerja dengan pendapatan karyawan diperoleh $\mathrm{r}_{2}=$ 0,514 yang berarti bahwa penyerapan tenaga kerja dengan pendapatan pegawai mempunyai pengaruh yang positif dengan kualifikasi agak rendah.

\section{Analisis Regresi \\ Linier Sederhana}

Y1 (penyerapan tenaga kerja)

$$
\begin{gathered}
\mathrm{y}=\mathrm{a}+\mathrm{bx} \\
\mathrm{b}=\frac{\mathrm{n}\left(\sum \mathrm{X} \mathrm{Y}_{1}\right)-\left(\sum \mathrm{X}\right)\left(\sum \mathrm{Y}_{1}\right)}{\mathrm{n} \sum \mathrm{X}^{2}-\left(\sum \mathrm{X}\right)} \\
=\frac{147355-143382}{2320-2112} \\
=\frac{3973}{204} \\
\mathrm{~b}=19,475
\end{gathered}
$$




$$
\begin{aligned}
& a=\frac{\sum Y-b \sum X}{n} \\
& =\frac{3117-895,87}{5}
\end{aligned}
$$$$
=2221.127
$$

$\mathrm{a}=444,225$

$\mathrm{x} \mathrm{Y}_{1}$

$\mathrm{Y}=444,225+19,475 \mathrm{X}$

$\mathrm{a}=444,2254902$ artinya konstanta yang menunjukkan volume produk walet konstanta $(\mathrm{x}=0)$ maka penyerapan tenaga kerja akan sebesar 444.2254902.

$b=19,475$ artinya koefisien regresi untuk variabel volume produk walet di peroleh nilai 19,475 mempunyai koefisien regresi positif hal ini menunjukkan bahwa setiap volume produk walet hal ini menunjukkan bahwa kenaikkan satu-satuan dari variabel volume produk walet akan menyebabkan peningkatan jumlah tenaga kerja sebesar 19,475.

Untuk Regresi Linier Y2 (pendapatan karyawan)

\begin{tabular}{|c|c|c|c|c|c|}
\hline Tahun & $\mathrm{X}$ & $\mathrm{Y} 2$ & $\mathrm{X}^{2}$ & $\mathrm{Y}^{2}$ & $\mathrm{XY}$ \\
\hline 2011 & 5 & 1.440 .000 & 25 & 2.073 .600 & 7.200 .000 \\
\hline 2012 & 7 & 1.920 .000 & 49 & 3.686 .400 & 13.440 .000 \\
\hline 2013 & 10 & 2.400 .000 & 100 & 5.760 .000 & 24.000 .000 \\
\hline 2014 & 11 & 5.040 .000 & 121 & 25.401 .600 & 55.440 .000 \\
\hline 2015 & 13 & 4.800 .000 & 169 & 23.040 .000 & 62.400 .000 \\
\hline$\sum$ & 46 & 15.600 .000 & 464 & 59.961 .600 & 162.480 .000 \\
\hline
\end{tabular}

Sumber Data : Di olah, Perusahaan PT. Perdana Jaya

Analisis regresi linier Y2 (pendapatan karyawan)

$$
\mathrm{b}=\frac{\mathrm{n}\left(\sum \mathrm{XY} \mathrm{Y}_{2}\right)-\left(\sum \mathrm{X}\right)\left(\sum \mathrm{Y}_{2}\right)}{\mathrm{n} \sum \mathrm{X}^{2}-\left(\sum \mathrm{X}\right)^{2}}
$$

$\mathrm{b}=812400000-717600000$

2320-2116

$\mathrm{b}=\underline{94800000}$

204

$b=464705,882$

$\mathrm{a}=\sum \mathrm{Y}-\mathrm{b} \sum \mathrm{X}$

n

$a=15600000-21376470,6$ 5

$\mathrm{a}=\underline{-5776470,59}$

5

$\mathrm{a}=-1155294$

$\mathrm{xY}_{2}$

$Y_{2}=-1155294+464.705,88 x$

Uji t

$t_{1}=\frac{r_{x y 1 \sqrt{n-2}}}{\sqrt{1-r_{x y 1}^{2}}}$

$t_{1}=\frac{0,582 \sqrt{5-2}}{\sqrt{1-0,582}}$

$t_{1}=\frac{1,697}{0,201}$

$t_{1}=8,426$

$\mathrm{t}_{\text {tabel }}$ dengan taraf signifikan $5 \%=$ 8,426

Jadi $t_{\text {hitung }}>t_{\text {tabel }}$ atau 8,426 $>$ 2,78

Dari hasil pengujian diatas dapat dibuat gambar kurva analisa t-test dua sisi sebagai berikut : 


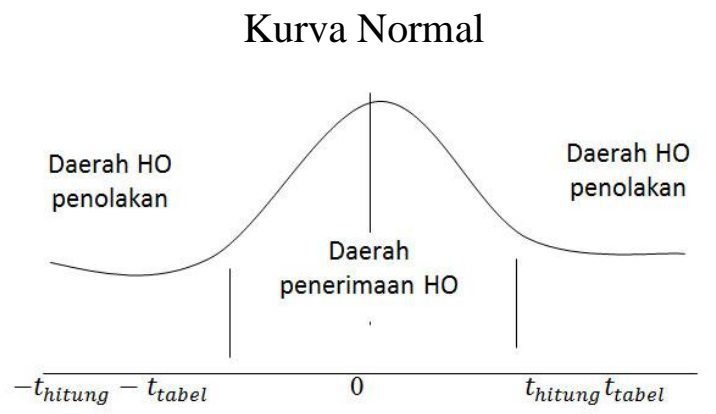

$t_{\text {hitung }}=8,246$ lebih besar dari $t_{\text {tabel }}=2,78$ hal ini berarti Ho ditolak maka ada hubungan atau pengaruh yang signifikan antara volume produk wallet dengan penyerakan tenaga kerja.

$$
\begin{gathered}
t_{\text {hitung } 2} \\
r_{x y 2}=\frac{r \sqrt{n-2}}{\sqrt{1-r^{2}}} \\
r_{x y 2}=\frac{0,883 \sqrt{5-2}}{\sqrt{1-0,883^{2}}} \\
r_{x y 2}=\frac{0,883 \sqrt{3}}{0,469} \\
r_{x y 2}=\frac{1,530}{0,469} \\
r_{x y 2}=3,263 \\
t_{\text {tabel }}=\text { taraf signifikan } 5 \%=2,78 \\
\text { Jadi } t_{\text {hitung }}>t_{\text {tabel }} \quad \text { atau } \\
\text { 3,263>2,78 } \\
\text { Korelasinya kuat }
\end{gathered}
$$

Dari hasil pengujian diatas, dapat dibuat gambar kurva analisa t-test dua sisi sebagai berikut :

\section{Kurva Normal}

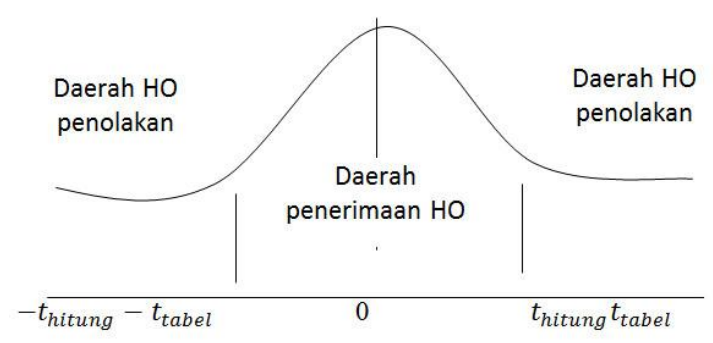

$t_{\text {hitung }}=3,263$ lebih besar dari $t_{\text {tabel }}=2,78$ hal ini berarti Ho ditolak maka ada hubungan atau pengaruh yang signifikan antara volume produk wallet dengan pendapatan karyawan.

\section{SIMPULAN DAN SARAN Simpulan}

Berdasarkan hasil penelitian maka dapat diambil beberapa kesimpulan yaitu:

1. Volume produk walet berpengaruh signifikan terhadap penyerapan tenaga kerja, dibuktikan dengan hasil dari Koefisien korelasi yang diperoleh $\mathrm{r}_{\mathrm{xy} 1}$ sebesar 0,98 dan $\mathrm{t}$ hitung sebesar 8,426 . Nilai t hitung yang diperoleh lebih besar dari t tabel sebesar 2,778 sehingga H0 ditolak dan Ha diterima.

2. Volume produk walet berpengaruh signifikan terhadap pendapatan karyawan Desa Tunggun Kecamatan Mantup. Di buktikan dengan hasil dari Koefisien korelasi yang diperoleh $\mathrm{r}_{\mathrm{xy} 2}$ sebesar 0,883 dan $\mathrm{t}$ hitung sebesar 3,266. Nilai t hitung yang diperoleh lebih besar dari t tabel sebesar 2,778 sehingga $\mathrm{H} 0$ ditolak dan Ha diterima.

3. Volume produk walet berpengaruh signifian terhadap penyerapan tenaga kerja, dibuktikan dari Hasil perhitungan persamaan regresi yang didapat $\mathrm{Y} 1$ $=444,225+19,475 \mathrm{X}$,

4. Volume produk walet berpengaruh signifikan terhadap pendapatan karyawan Desa Tunggun Kecamatan Mantup Kabupaten Lamongan, dibuktikan dari Hasil perhitungan persamaan regresi yang didapat $Y_{2}=$ 1.155.294 + 464.705,88 X,

Hendaknya volume produk walet lebih meningkatkan lagi target 
produksinya. Dan dari hasil penelitian volume produk walet mempunyai pengaruh yang singnifikan terhadap penyerapan tenaga kerja dan pendapatan karyawan desa Tunggun Kec. Mantup Kab. Lamongan.

\section{DAFTAR PUSTAKA}

Afrida. 2007. Ekonomi Sumber Daya Manusia. Jakarta: Ghalia Indonesia.

Andi supangat. 2006. Statistik Dalam Kajian Defkriftif, Iferensi Dan Nonparametik. Edisi pertama Jakarta: Kencana prenada media group.

Arsyad. 2006. Media Pembelajaran. Jakarta: Rajawali pers.

Dumairy. 2009. Indonesia Perekonomian. Edisi 3. Jakarta: Erlangga.

Hasmoenir. 2010. Manajemen Pelayanan Umum Di Indonesia. Jakarta: Bumi aksara.

Herlin Sulistyo. 2015. Analisis Industri Kecil Bordir Jilbab Terhadap Penyerapan Tenaga Kerja dan Pendapatan Masyarakat di Desa Sendangagug Kec.Paciran Kab. Lamongan.

Novita Amaliya. 2014. Pengauh Adanya Industri Kerajinan Songkok Terhadap Tingkat Pendapatan Masyarakat Desa Bojoasri Kec. Mantup Kab. Lamongan

Suharsimi. 2010. Prosedur Metode Penelitian. Yogyakarta

Suharyadi dan purwanto S.K. 2013. Statistik Untuk Ekonomi Dan Keuangan Modern. Jakarta.
Undang-undang Republik Indonesia No. 20 Tahun 2008 tentang usaha besar

Tim Penulis PS. Budidaya dan Bisnis Sarang Walet.Cet. 4. Jakarta: Penebar Swadaya, 1994.

Pedoman umum penyusunan skripsi, FE. 2014. Universitas Islam Lamongan (UNISLA)

http://maliqren.wordpress.com/2010/1 1/19/masyarakat-pedesaan/ 